\title{
Role of Hippocampal CA3 $\mu$-Opioid Receptors in Spatial Learning and Memory
}

\author{
William J. Meilandt, Edwin Barea-Rodriguez, Stephen A. K. Harvey, and Joe L. Martinez Jr \\ Cajal Neuroscience Institute, Department of Biology, University of Texas at San Antonio, San Antonio, Texas 78249-0662
}

The dorsal CA3 region of the hippocampus is unique in its connectivity, sensitivity to neurotoxic lesions, and its ability to encode and retrieve episodic memories. Computational models of the CA3 region predict that blocking mossy-fiber and/or perforant path activity to CA3 would cause impairments in learning and recall of spatial memory, respectively. Because the CA3 region contains $\mu$-opioid receptors and receives inputs from the mossy-fiber and lateral perforant pathways, both of which contain and release opioid peptides, we tested the hypothesis that inactivating $\mu$-opioid receptors in the CA3 region would cause spatial learning and memory impairments and retrieval deficits. In this study, male Sprague Dawley rats were trained in a Morris water maze after a single bilateral intrahippocampal injection of either saline or the selective and irreversible $\mu$-opioid receptor antagonist $\beta$-funaltrexamine ( $\beta$-FNA) into area CA3. We found that $\mu$-opioid receptor binding decreased $24 \mathrm{hr}$ after $\beta$-FNA injection and returned to control levels $11 \mathrm{~d}$ after injection. Injections of $\beta$-FNA into the CA3 region, but not into the ventricles, caused a significant impairment in the acquisition of spatial learning without causing sensory or motor deficits. New learning was not affected once $\mu$-opioid receptor levels replenished ( $>11 \mathrm{~d}$ after injection). In pretrained animals, $\beta$-FNA significantly impaired spatial memory retrieval and new (reversal) learning. These data are consistent with theoretical models of $\mathrm{CA} 3$ function and suggest that $\mathrm{CA} 3 \mu$-opioid receptors play an important role in the acquisition and retrieval of spatial memory.

Key words: hippocampus; CA3; $\mu$-opioid receptor; water maze; spatial learning; memory retrieval

\section{Introduction}

The hippocampus is an essential neural structure involved in the formation of certain types of memory (Olton et al., 1978; Morris et al., 1982; Zola-Morgan et al., 1986). For instance, temporary inactivation or lesions ( $\geq 25 \%$ ) of the dorsal hippocampus cause impairments in the acquisition and retrieval of spatial memory in tasks such as the Morris water maze (Moser et al., 1993; Moser and Moser, 1998; Riedel et al., 1999). Furthermore, selective neurotoxic lesions of the $\mathrm{CA} 3$ region cause spatial learning and memory impairments (Handelmann and Olton, 1981; Sutherland et al., 1983; Stubley-Weatherly et al., 1996), suggesting that this subregion of the hippocampus plays a significant role in spatial memory formation.

The leading synaptic model for information storage in the hippocampus is an activity-dependent form of synaptic plasticity called long-term potentiation (LTP) (Bliss and Collingridge, 1993). Unlike the recurrent collaterals and medial perforant path,

\footnotetext{
Received Dec. 18, 2003; revised Jan. 29, 2004; accepted Jan. 30, 2004.

This work was supported by National Institute on Drug Abuse Grants F31 DA14746-01 (W.J.M.) and R01 DA 04195 (J.L.M.), Research Centers in Minority Institutions Grants RR 13646 (J.L.M. and E.J.B.) and S06 GM 08194 (E.J.B), and by the Ewing Halsell Foundation (J.L.M.). We thank J. B. Grisby and J. M. Keel for their technical assistance and Drs. Alan Frazer and Georgina Gould at the University of Texas Health Science Center in San Antonio for their assistance in the autoradiography experiments. Some of these data have been published previously in abstract form (Meilandt et al., 1999).

Correspondence should be addressed to Dr. William J. Meilandt, Cajal Neuroscience Institute, Department of Biology, University of Texas San Antonio, 6900 North Loop 1604 West, San Antonio, TX 78249. E-mail wmeiland@lonestar.utsa.edu.

S. A. K. Harvey's present address: Department of Ophthalmology, University of Pittsburgh, 203 Lothrop Street, Pittsburgh, PA 15213.

DOI:10.1523/JNEUROSCI.5569-03.2004

Copyright $\odot 2004$ Society for Neuroscience $\quad 0270-6474 / 04 / 242953-10 \$ 15.00 / 0$
}

the type of LTP found at the mossy fiber to CA3 and lateral perforant path to CA3 or dentate synapses is not dependent on the activation of NMDA receptors (Harris and Cotman, 1986), but instead, involve $\mu$-opioid receptors (Bramham et al., 1988; Derrick et al., 1992; Bramham and Sarvey, 1996; Williams and Johnston, 1996), among others (Yeckel et al., 1999; Lauri et al., 2001). Opioid receptors $(\mu, \kappa$, and $\delta)$ are abundant in the hippocampus and are activated by opioid peptides, coreleased with glutamate, from mossy-fiber and lateral perforant path synapses (Stengaard-Pedersen, 1983; Mansour et al., 1987; Conner-Kerr et al., 1993). Opioids are also known to modulate the excitability of hippocampal pyramidal neurons (Zieglgansberger et al., 1979; Simmons and Chavkin, 1996b), whereas $\mu$-opioid receptor antagonists (Breindl et al., 1994; Derrick and Martinez, 1994a; Bramham and Sarvey, 1996) or $\mu$-opioid receptor gene deletions (Matthies et al., 2000; Jamot et al., 2003; Jang et al., 2003) block the induction of both mossy-fiber LTP to CA3 and lateralperforant-path LTP to CA3 and dentate and impair spatial water maze learning. However, the specific role of CA $3 \mu$-opioid receptors has not been identified for spatial learning.

On the basis of lesion studies and anatomical features of the hippocampus, several computational models have been developed to study how the hippocampus acquires, encodes, and retrieves spatially and temporally coded information. It is believed that the CA3 region acts as an autoassociative network (Marr, 1971) that is capable of storing episodic memories, by virtue of its extensive recurrent collaterals (Ishizuka et al., 1990), and that incoming information entering the CA3 via the mossy-fiber and perforant pathways play a critical role in the establishment and recall of context-dependent memories (McNaughton and Mor- 
ris, 1987; Treves and Rolls, 1992, 1994; Hasselmo et al., 1995). The mossy-fiber input to CA3 is particularly important during learning and is often considered the "teaching synapse," whereas the perforant-path input to CA3 is thought necessary for recalling previously learned information (Treves and Rolls, 1992, 1994).

Although there are many computational models of CA3 function, there are few behavioral studies to support their predictions. Several models predict that temporary inactivation of the mossyfiber and perforant path to CA3 synapses would impair learning and retrieval of spatial memories (Treves and Rolls, 1992, 1994). We tested this hypothesis by training animals in a water maze task $24 \mathrm{hr}$ or $11 \mathrm{~d}$ after a bilateral injection of saline or the selective and irreversible $\mu$-opioid receptor antagonist $\beta$-funaltrexamine ( $\beta$ FNA) (Portoghese et al., 1980; Martin et al., 1993) into the dorsal CA3 region of the hippocampus. We also investigated the effects of $\beta$-FNA on spatial memory retrieval and new learning in pretrained animals. Control experiments were performed using a visual platform version of the water maze.

\section{Materials and Methods}

Animals. Male Sprague Dawley rats (350-375 gm; Charles River, Wilmington, MA) were housed individually, provided with food and water ad libitum, and kept on a $12 \mathrm{hr}$ light/dark cycle. To reduce stressmediated effects on behavior (Holscher, 1999); animals were allowed to rest for 1 week after arrival and were handled (1-2 min, three times a week) before surgery and training. All experimental protocols followed National Institutes of Health guidelines and were approved by the University of Texas at San Antonio Institutional Animal Care and Use Committee.

Surgical procedures. For permanent implantation of cannula, animals were anesthetized with $50 \mathrm{mg} / \mathrm{kg}$ sodium pentobarbital. Using standard stereotaxic techniques, bilateral 26 gauge stainless steel guide cannulas (model C315GA; Plastics One, Roanoke, VA) were implanted into the $\mathrm{CA} 3$ region of the dorsal hippocampus (anteroposterior, $-3.5 \mathrm{~mm}$; mediolateral, $\pm 3.8 \mathrm{~mm}$; dorsoventral, $-2.7 \mathrm{~mm}$ from the bregma) (Paxinos and Watson, 1998). Each guide cannula was fitted with a dummy cannula extending $0.5 \mathrm{~mm}$ below the guide cannula to a final depth of $3.2 \mathrm{~mm}$ below the skull. Cannulas were permanently mounted to the skull with two to three head screws and dental cement. Animals received an intramuscular injection of penicillin (22500 U) into each thigh after the surgery and were given water treated with acetaminophen $(0.32 \mathrm{mg} / \mathrm{ml})$ for $3 \mathrm{~d}$. Animals were allowed 5-7 d to recover from surgery before injections and training. For acute injections, an internal 33-gauge stainless steel cannula (model C315IA; Plastics One) was inserted extending $0.5 \mathrm{~mm}$ below the guide cannula to a final depth of $3.2 \mathrm{~mm}$ from the skull.

Drug injections. $\beta$-FNA was obtained from RBI Sigma (St. Louis, MO). Tritiated $\beta$-FNA $\left(\left[{ }^{3} \mathrm{H}\right]-\beta\right.$-FNA) was obtained from the National Institute on Drug Abuse, Division of Neuroscience and Behavioral Research.

Animals were anesthetized with sodium pentobarbital to ensure complete delivery of a single bilateral intrahippocampal injection of $0.9 \%$ saline or $\beta$-FNA ( $40 \mathrm{nmol}$ in $0.9 \%$ saline, $\mathrm{pH} 7.4-7.8$ ). A stock solution of $12 \mathrm{~mm} \beta$-FNA was first dissolved in water, then $\mathrm{NaCl}$ was added to achieve a $0.9 \%$ saline solution. Sodium hydroxide was used to adjust the $\mathrm{pH}$. Both drug and saline were made up in pyrogen-free water. An equal volume $(3.33 \mu \mathrm{l})$ of either saline or $\beta$-FNA was administered at a rate of $0.333 \mu \mathrm{l} / \mathrm{min}$ for $10 \mathrm{~min}$ through a 33 -gauge internal cannula connected via polyethylene tubing to a $10 \mu \mathrm{l}$ Hamilton syringe. A Harvard syringe pump was used for delivery. Five minutes after the completion of the injections, the internal cannulas were removed and replaced with dummy cannulas. The experimenter was unaware of which animals received saline or $\beta$-FNA.

Behavioral training. Animals were trained in a Morris water maze (Morris et al., 1982), consisting of a galvanized steel pool (150 cm diameter, $60 \mathrm{~cm}$ deep $)$ filled with water $\left(25 \pm 1^{\circ} \mathrm{C}\right)$ and made opaque with nontoxic water-soluble paint. Salient extramaze cues were placed on the walls around the room. The position of the animals during the task was monitored and recorded using a ceiling-mounted video camera con- nected to a computerized tracking/imaging analyzer system (HVSImage, Hampton, UK; Watermaze Software, Edinburgh, UK).

Experiment 1 investigated the effects of $\beta$-FNA on spatial learning performance and reversal learning after a $6 \mathrm{~d}$ retention interval (see Fig. 1A). Experiment 2 investigated the effect of $\beta$-FNA on spatial learning $11 \mathrm{~d}$ after injection. Experiment 3 investigated the effect of $\beta$-FNA on visual platform training. Experiment 4 investigated the effects of $\beta$-FNA on memory retrieval and new learning in pretrained animals (see Fig. $5 A$ ).

Animals were trained to find a single hidden platform $(12 \mathrm{~cm}$ diameter) in one of four quadrants (NE, SE, SW, NW) that was submerged $3 \mathrm{~cm}$ below the water level. For each trial, animals were released into the water facing the edge of the pool from one of four equally spaced locations $(\mathrm{N}$, $\mathrm{S}, \mathrm{E}, \mathrm{W}$ ) in a pseudorandom order and allowed $60 \mathrm{sec}$ to escape onto the platform. If the animals did not find the platform after $60 \mathrm{sec}$, they were guided to the platform, where they were allowed to remain for $15 \mathrm{sec}$. Each animal underwent five trials per day for 5 consecutive days. A spatial probe trial was conducted after the final training trial on days 1,3 , and 5 , which consisted of a $60 \mathrm{sec}$ swim trial in the absence of the platform. Six days after the last day of training (day 11), animals were given a single 60 sec probe trial to examine memory retention. Animals were then trained to find a hidden platform in the opposite quadrant for 5 additional days (reversal training). Spatial probe trials were performed on days 11, 13, and 15 of reversal training.

In experiment 1 , animals began training $24 \mathrm{hr}$ after injections of either saline $(n=7)$ or $\beta$-FNA $(n=7)$. Three saline control animals were removed from the study during the reversal training because of complications with the head stage. In experiment 2 , an additional set of animals was trained in the water maze $11 \mathrm{~d}$ after receiving injections of $\beta$-FNA $(n=5)$ or saline $(n=7)$. Training consisted of five trials per day for 5 consecutive days. Spatial probe trials were given after the final training trial on days 1,3 , and 5 . In experiment 3 , an additional set of $\beta$-FNA $(n=$ $5)$ and saline-treated animals $(n=4)$ were trained to find a visual platform raised $1.5 \mathrm{~mm}$ above the water. A ping-pong ball was attached 6 inches above the platform. Training consisted of five trials per day for $3 \mathrm{~d}$. In experiment 4 , animals underwent spatial pretraining consisting of five trials per day for 5 consecutive days. After the completion of pretraining, animals were matched and separated into two groups that had similar average escape latency values over the $5 \mathrm{~d}$ of training. One group $(n=11$; average escape latency, $20.8 \pm 3 \mathrm{sec}$ ) received $\beta$-FNA, whereas the control group $(n=11$; average escape latency, $21.0 \pm 2.8 \mathrm{sec})$ received an injection of $0.9 \%$ saline. Drug injections were administered on day $9,2 \mathrm{~d}$ before the retrieval test and reversal training (see timeline in Fig. 5A).

Statistical analysis. One-way and two-way repeated-measures ANOVAs were used to determine statistical significance of the drug treatment ( $\beta$-FNA or saline) as the between factor, and days of training and percentage of time spent in the probe trial quadrants or zones as the within factor. The StudentNewman-Keuls test was used to determine significance during preplanned post hoc analysis.

Autoradiography. To determine the level and distribution of irreversible $\mu$-opioid receptor binding by $\beta$-FNA, a separate group of naive animals were implanted with bilateral cannulas and injected with unlabeled $\beta$-FNA ( $40 \mathrm{nmol} ; n=4)$ or saline $(n=4)$ (as described above). Half of the $\beta$-FNA and saline-treated animals then received a unilateral injection of $\beta$-FNA ( $40 \mathrm{nmol}$ ) containing $0.6 \mu \mathrm{Ci}$ of tritiated $\left[{ }^{3} \mathrm{H}\right] \beta$-FNA into the right cannula either $24 \mathrm{hr}(\beta$-FNA, $n=2$; saline, $n=2)$ or $11 \mathrm{~d}$ ( $\beta$-FNA, $n=2$; saline, $n=2$ ) after the unlabeled injection of $\beta$-FNA or saline. The $\left[{ }^{3} \mathrm{H}\right] \beta$-FNA would therefore compete with unlabeled $\beta$-FNA for the remaining available $\mu$-receptor binding sites. The density of $\left[{ }^{3} \mathrm{H}\right] \beta$-FNA binding would reflect the amount of available $\mu$-opioid receptor binding sites. Animals were killed $24 \mathrm{hr}$ after the $\left[{ }^{3} \mathrm{H}\right] \beta$-FNA infusion, and their brains were removed and frozen. Every third coronal section $(20 \mu \mathrm{m})$ was collected and thaw-mounted onto gelatin-coated slides. Slides were dried overnight at $4^{\circ} \mathrm{C}$ in a vacuum desiccator, and then stored at $-20^{\circ} \mathrm{C}$. Slides were washed at room temperature in series of $50 \mathrm{~mm}$ Tris- $\mathrm{HCl}, \mathrm{pH} 7.4$, baths for 1 and $5 \mathrm{~min}$, and twice for $20 \mathrm{~min}$ (Liu-Chen et al., 1991). Slides were briefly washed in water to remove salts and were dried quickly under cool air and exposed to film (Hyperfilm $\left[{ }^{3} \mathrm{H}\right]$; Amersham Biosciences, Piscataway, NJ) along with calibrated microscale standards (ART-123, 123A; American Radiolabeled Chemi- 

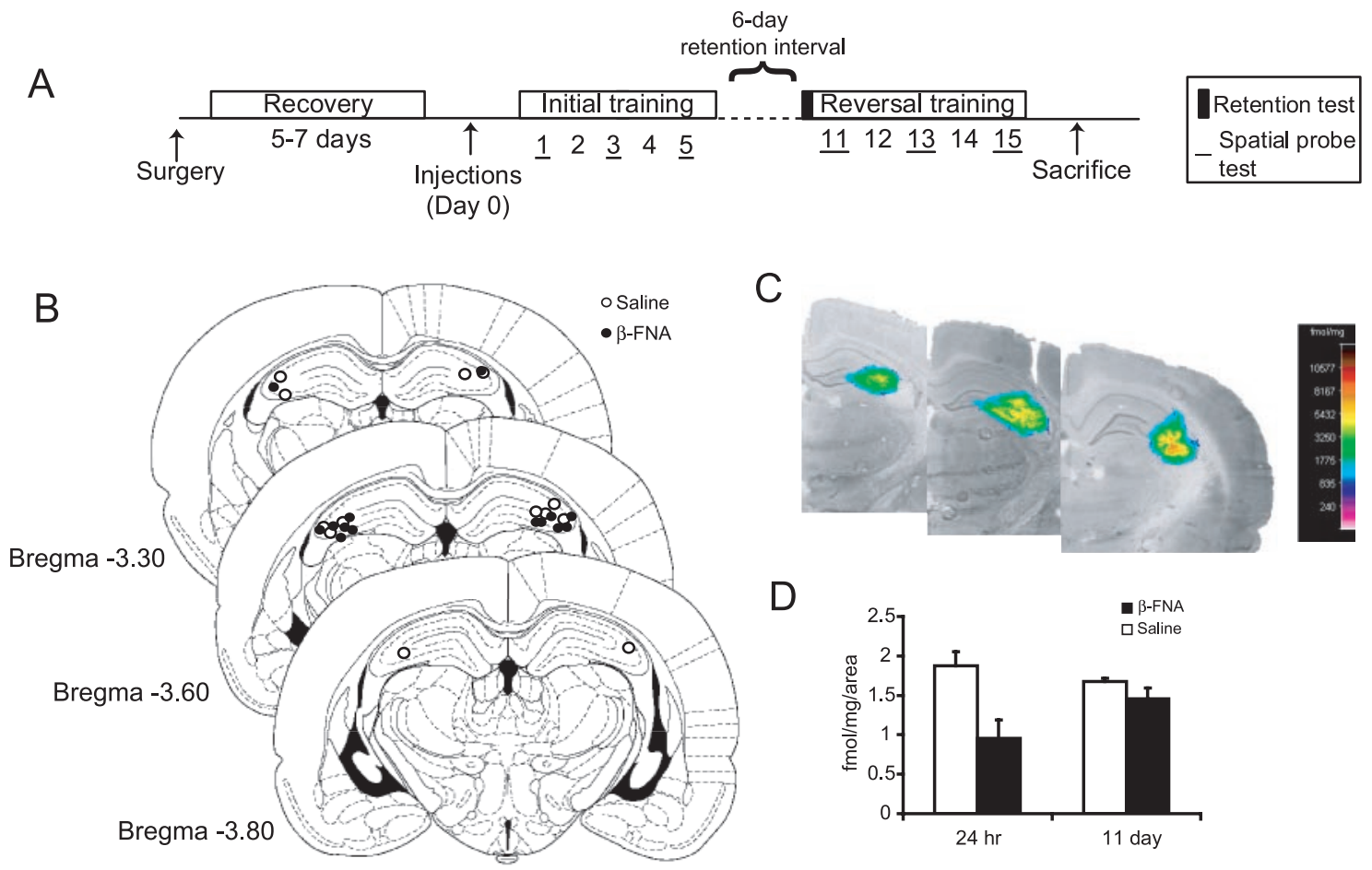

Figure 1. Effects of $\beta$-FNA on $\mu$-opioid receptor binding. $A$, Animals were bilaterally implanted with guide cannulas into the dorsal CA3 region of the hippocampus and allowed to recover for 5 -7 $\mathrm{d}$ before receiving a single injection of $\beta$-FNA ( $40 \mathrm{nmol}$ ) or saline. Animals were trained in a water maze for 5 consecutive days, followed by a $6 \mathrm{~d}$ retention interval then 5 additional days of reversal training. Spatial probe trials were given after the last trial on the first, third and fifth day of initial and reversal training. A probe trial was given at the beginning of day 11 to test for memory retention for the previously learned platform position. B, Location of cannula tips for animals treated with $\beta$-FNA (solid circles) and saline (open circles). Plates were adapted from Paxinos and Watson (1998). C, Location and spread of irreversibly bound $\left[{ }^{3} \mathrm{H}\right] \beta$-FNA overlaid on an image of a coronal brain section. The pseudocolor scale is in femtomoles per milligram of tissue. D, Effects of $\beta$-FNA (black columns) or saline (white columns) on the irreversible binding of [ $\left.{ }^{3} \mathrm{H}\right] \beta$-FNA to $\mu$-opioid receptors $24 \mathrm{hr}$ and $11 \mathrm{~d}$ after injection.

cals, St. Louis, MO). Five to 6 weeks later, the films were developed following standard procedures and were analyzed using a microcomputer imaging device image-analysis system (Imaging Research, St. Catharines, Ontario, Canada). Distribution of the injected $\left[{ }^{3} \mathrm{H}\right] \beta$-FNA within the hippocampus and surrounding regions was visualized, and binding density of $\left[{ }^{3} \mathrm{H}\right] \beta$-FNA (fmol/mg tissue/total area in pixels) was determined from an average of four to eight sections per animal for $\beta$-FNA and saline-treated animals $24 \mathrm{hr}$ or $11 \mathrm{~d}$ after injection.

Histology. All animals from experiments 1-4 were killed and perfused with $4 \%$ formalin within $48 \mathrm{hr}$ of the completion of the experiment. The brains of all animals were removed and stored in formalin for $2 \mathrm{~d}$; they were then frozen and sectioned at $-20^{\circ} \mathrm{C}$. Coronal sections $(25 \mu \mathrm{m})$ were stained with the Nissl stain, thionine, to check for cannula placement. Data from animals with cannula misplacements during training were removed from the study (see below).

\section{Results}

\section{Histology and autoradiography}

After the completion of each experiment, animals were killed and their brains were removed for histological examination to determine cannula location. Inclusion of animals into the behavioral analysis was dependent on the cannula tips remaining within the CA3 region of the dorsal hippocampus. Cannula locations for experiment 1 are seen in Figure $1 B$. Three animals were removed from this study because of cannula misplacements. Animals with cannulas located in the lateral ventricles $(n=13)$ were analyzed separately and compared with animals having cannulas in the CA3 region.

$\beta$-FNA is the $\beta$-fumaramate methyl ester of naltrexamine, first synthesized by Portoghese et al. (1980). It is known to possess long-lasting irreversible $\mu$-receptor antagonistic activity both in vitro (Portoghese et al., 1980; Takemori et al., 1981) and in vivo
(Ward et al., 1982; Rothman et al., 1988; Martin et al., 1993) by covalently binding to lysine 233 in the third extracellular loop of the $\mu$-opioid receptor (Chen et al., 1996). Irreversible binding of $\left[{ }^{3} \mathrm{H}\right] \beta$-FNA thus provides a measure of functional $\mu$-opioid receptors in situ. An example autoradiogram (Fig. 1C) shows that labeling by infused $\left[{ }^{3} \mathrm{H}\right] \beta$-FNA is localized predominantly to the dorsal CA 3 region of the hippocampus. Intrahippocampal injections of unlabeled $\beta$-FNA caused a $49.2 \%$ reduction in subsequent $\left[{ }^{3} \mathrm{H}\right] \beta$-FNA binding to $\mu$-opioid receptors at $24 \mathrm{hr}$ and a $13.1 \%$ reduction $11 \mathrm{~d}$ later (Fig. $1 D)$.

\section{Injection of $\boldsymbol{\beta}$-FNA into the dorsal CA3 region impairs spatial learning}

As outlined in Figure $1 A$, animals in experiment 1 received a single injection of $\beta$-FNA ( $40 \mathrm{nmol} ; n=7)$ or saline $(n=7)$ into the dorsal CA 3 region of the hippocampus $24 \mathrm{hr}$ before training in the reference memory version of the Morris water maze (Morris et al., 1982). Inactivation of CA3 $\mu$-opioid receptors with $\beta$-FNA significantly impaired the acquisition of spatial learning (Fig. 2A) compared with saline-treated controls. Saline control animals learned this task well, spending less time each day to find the platform and reaching asymptotic performance by the fourth day of training with escape latencies $<20 \mathrm{sec}$, whereas the $\beta$-FNA-treated animals learned this task at a much slower rate. A two-way repeated-measures ANOVA of escape latencies found a significant treatment effect $\left(F_{(1,12)}=8.2 ; p=0.01\right)$, days effect $\left(F_{(4,48)}=15.9 ; p<0.001\right)$, and no treatment $\times$ days interaction $\left(F_{(4,48)}=0.59 ; p>0.5\right)$. Similar impairments were seen in the swim distances (Fig. $2 B$ ) (treatment effect, $F_{(1,12)}=5.1 ; p<0.05$; days effect, $\left.F_{(4,48)}=10.5 ; p<0.001\right)$ and in the percentage of time 
A

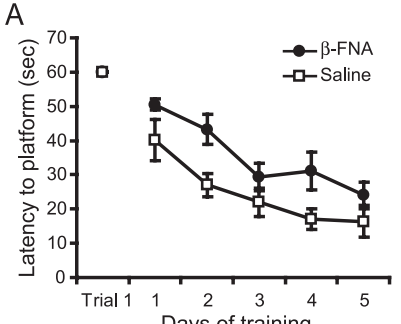

$\mathrm{B}$
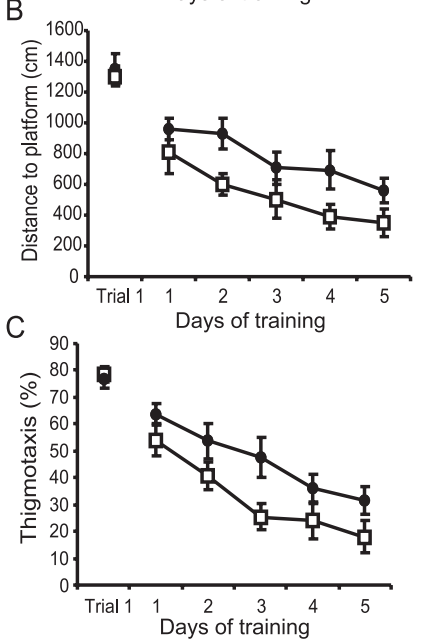

D

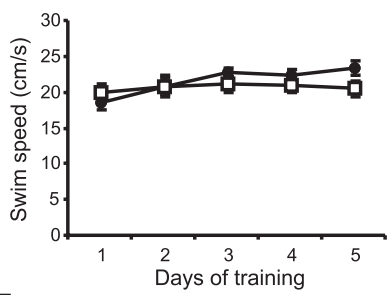

E

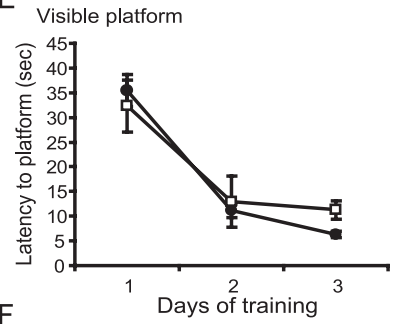

$\mathrm{F}$

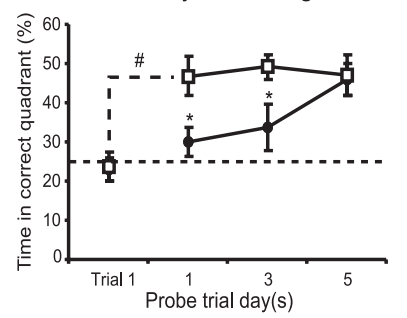

Figure 2. Effects of $\beta$-FNA on spatial water maze learning $24 \mathrm{hr}$ after injection. Mean \pm SEM escape latencies $(A)$, distance traveled $(B)$, amount of time spent swimming in the outer $20 \%$ of the pool (thigmotaxis) (C), and swim speeds (D) during the initial $5 \mathrm{~d}$ of training for animals treated with $\beta$-FNA (solid circles) and saline (open squares). Performance on trial 1 is also shown. $E$, Latency to find a visible platform in a separate group of animals. Spatial probe trials were given after the last trial on the first, third, and fifth day of initial training. $F$, The rate of spatial memory formation was determined by monitoring the percentage of time spent in the correct quadrant during the first trial of day 1 and during the subsequent probe trials. The dashed line represents chance performance levels $(25 \%)$. Significance differences were found. ${ }^{*} p<0.05$ versus control; ${ }^{* *} p=0.007$ versus trial 1 .

spent in the outer $20 \%$ of the pool, or thigmotaxis (Fig. 2C) (treatment effect, $F_{(1,12)}=5.69 ; p<0.05$; days effect, $F_{(4,48)}=$ $20.0 ; p<0.001)$. There were no differences in the latencies or distance to the platform on the first trial of day 1 ; moreover, no significant differences were found in swim speeds (Fig. 2D) (treatment effect, $F_{(1,14)}=0.006 ; p>0.5$ ) or visible platform performance (Fig. $2 E$ ) (treatment effect, $F_{(1,7)}=0.098 ; p>0.5$ ), suggesting that there were no overt behavioral deficits, such as an inability to swim or see the platform, as a result of the $\beta$-FNA injections.

To determine whether the learning impairments induced by $\beta$-FNA were specific for the $\mu$-opioid receptors in the CA 3 region of the hippocampus, spatial learning was tested in animals that had cannulas located in the lateral ventricles. Intraventricular injections of $\beta$-FNA did not impair spatial learning. There were no significant differences in the escape latencies between animals treated with saline $(n=8)$ and $\beta$-FNA $(n=5)$ (data not shown). A repeated-measures ANOVA of escape latencies revealed a significant days effect $\left(F_{(4,44)}=15.5 ; p<0.001\right)$, but neither a significant treatment effect $\left(F_{(1,11)}=2.8 ; p>0.1\right)$ nor a treatment $\times$ days interaction $\left(F_{(4,44)}=0.14 ; p=0.97\right)$.

Inactivation of CA3 $\mu$-opioid receptors with $\beta$-FNA significantly impaired the rate of spatial memory formation. A summary of the effects of $\beta$-FNA on probe trial performance, as measured by the percentage of time spent in the correct quadrant, is seen in Figure $2 F$. Saline- and $\beta$-FNA-treated animals spent a

similar amount of time in the correct quadrant during the first trial on day 1; however, by the end of the first day training (probe day 1 ) the saline-treated animals spent significantly more time in the correct quadrant $(p=0.007)$ compared with trial 1 , whereas there was no change in the performance of the $\beta$-FNA-treated animals $(p>0.1)$. In addition, $\beta$-FNA significantly impaired the rate of spatial memory formation measured over probe days 1, 3, and 5. A repeated-measures ANOVA of the percentage of time spent in the correct quadrant between the saline and $\beta$-FNAtreated animals showed a significant treatment effect $\left(F_{(1,12)}=\right.$ $10.6 ; p=0.007)$. Subsequent comparisons using the StudentNewman-Keuls test showed that the $\beta$-FNA-treated animals spent significantly less time in the correct quadrant than salinetreated animals $(p<0.05)$ on probe days 1 and 3 .

Although the $\beta$-FNA-treated animals were significantly impaired in the acquisition of this task, they eventually learned to locate the position of the platform by the last day of training (probe day 5) (Fig. 2 F). Both saline- and $\beta$-FNA-treated animals spent significantly more time searching in the correct quadrant than all other quadrants during the $60 \mathrm{sec}$ probe trial (one-way ANOVA; $p<0.001$ ). A two-way repeated-measures ANOVA of the percentage of time spent in the four quadrants showed no significant treatment $\times$ quadrant interaction $\left(F_{(3,36)}=0.04 ; p>\right.$ $0.5)$. Subsequent comparisons found no differences in the amount of time spent in the correct quadrant $(p>0.1)$.

\section{Injection of $\boldsymbol{\beta}$-FNA into the dorsal CA3 region impairs spatial memory retention}

Memory retention for the previously learned platform position was tested $6 \mathrm{~d}$ after the last day of training ( $11 \mathrm{~d}$ after injection) by giving animals a $60 \mathrm{sec}$ probe trial (Fig. 3A). Although the $\beta$-FNA-treated animals formed a spatial memory for the platform position by the last day of training (probe day 5 ) (Fig. 2 F), this memory was not accessible. Only the saline-treated animals remembered the platform position, evidenced by spending significantly more time in the correct quadrant than in all other quadrants (one-way ANOVA; $F_{(3,18)}=6.63 ; p=0.003$ ), whereas the $\beta$-FNA-treated animals failed to show a quadrant preference (one-way ANOVA; $F_{(3,18)}=1.25 ; p>0.1$ ). An example of the swim paths is seen in Figure $3 B$. The saline-treated animals spent $40.5 \pm 4.8 \%$ (means \pm SEM) of the time in the correct quadrant, whereas the $\beta$-FNA-treated animals performed at approximately chance levels by spending only $25.8 \pm 2.5 \%$ of the time in the correct quadrant. A two-way repeated-measures ANOVA of the percentage of time spent in the four quadrants between the saline and $\beta$-FNA-treated animals revealed a significant treatment $\times$ quadrant interaction $\left(F_{(3,36)}=4.5 ; p<0.01\right)$. Subsequent comparisons using the Student-Newman-Keuls test revealed that the $\beta$-FNA-treated animals spent significantly less time in the correct quadrant $(p=0.002)$ than did saline control animals.

\section{Reversal learning is not impaired once $\boldsymbol{\mu}$-opioid receptor levels replenish}

To demonstrate that the learning impairments induced by $\beta$-FNA were reversible, we used a within-animal design to investigate whether the previously impaired $\beta$-FNA-treated animals could learn a new task once $\mu$-opioid receptor levels replenished. As seen in Figure $1 D$, at $11 \mathrm{~d}$ after injection there was an equivalent amount of $\mu$-opioid receptor binding between saline- and $\beta$-FNA-treated animals. Therefore, immediately after the retention test on day 11, animals were trained to find a hidden platform in the opposite quadrant (reversal learning) for an additional $5 \mathrm{~d}$ (see Materials and Methods). 


\section{A Retention Test}

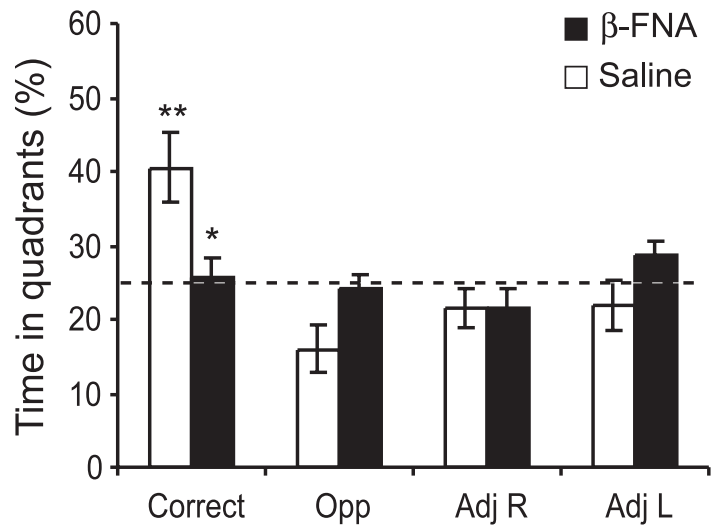

Figure 3. Effects of $\beta$-FNA on memory retention measured $6 \mathrm{~d}$ after training. A spatial probe trial was given at the beginning of day 11 to access memory retention for the previously learned platform position. $A$, The percentage of time spent in the correct and the three other corresponding quadrants were determined (means \pm SEM) for the $\beta$-FNA (solid bars) and saline (open bars) treated animals. Note that the $\beta$-FNA-treated animals are spending close to chance levels in all quadrants. The dashed line represents chance levels (25\%). Significant differences were found. ${ }^{*} p=0.002$ versus control; ${ }^{* *} p<0.001$ versus all other quadrants. $B$, Representative swim paths for $\beta$-FNA (left) and saline-treated (right) animals. The correct quadrant is outlined with a dashed line.

Reversal learning was not impaired in the $\beta$-FNA-treated animals (Fig. 4A). Both saline and $\beta$-FNA-treated animals achieved the task, reaching asymptotic performance with escape latencies $<12 \mathrm{sec}$ by the end of training. A two-way repeated-measures ANOVA of escape latencies between the saline and $\beta$-FNAtreated animals revealed a significant days effect $\left(F_{(4,36)}=10.0\right.$; $p<0.001)$, but neither a significant treatment effect $\left(F_{(1,9)}=2.0\right.$; $p>0.1)$ nor a treatment $\times$ days interaction $\left(F_{(4,36)}=0.11 ; p=\right.$ 0.98 ). Similar results were seen in the swim distances (Fig. $4 I$ ) (treatment effect, $F_{(1,9)}=2.4 ; p>0.1$ ), thigmotaxis (treatment effect, $F_{(1,9)}=3.3 ; p>0.1$ ), and swim speeds (Fig. $4 C$ ) (treatment effect, $\left.F_{(1,11)}=0.016 ; p>0.5\right)$. Moreover, reversal learning was not impaired in animals receiving injections of saline or $\beta$-FNA into the ventricles (latency data not shown; $F_{(1,8)}=0.03 ; p>0.5$ ). Spatial memory was not impaired in the $\beta$-FNA-treated animals during the reversal training, as evidenced by probe trial performance (Fig. 4D). A two-way repeated-measures ANOVA of the percentage of time spent in the correct quadrant over probe days 11,13 , and 15 revealed no significant treatment effect $\left(F_{(1,9)}=\right.$ $0.19 ; p>0.5$ ). Subsequent comparisons (Student-NewmanKeuls) showed that the saline and $\beta$-FNA-treated animals spent an equivalent amount of time in the correct quadrant $(p>0.1)$ on all reversal probe days. However, it was noted that on probe day 11 , the saline-treated animals were spending significantly more time searching in the correct quadrant than all other quadrants (one-way ANOVA; $F_{(3,9)}=6.6 ; p<0.05$ ), unlike the $\beta$-FNA-treated animals $\left(F_{(3,9)}=0.29 ; p>0.5\right)$, suggesting that although $\mu$-opioid receptor levels are equivalent between the saline and $\beta$-FNA-treated animals (Fig. $1 D$ ), $\beta$-FNA may still have some residual effect on spatial memory.

To investigate this finding further, an additional group of animals were trained in the water maze $11 \mathrm{~d}$ after receiving injections of either saline $(n=7)$ or $\beta$-FNA $(n=5)$ into the dorsal CA3 region of the hippocampus. As seen in Figure $4 E$, spatial learning, as measured by escape latencies, was not impaired $11 \mathrm{~d}$ after injection. Both saline- and $\beta$-FNA-treated animals acquired the task, reaching asymptotic performance with escape latencies $<15 \mathrm{sec}$ by the end of training. A two-way repeated-measures
ANOVA of escape latencies between the saline- and $\beta$-FNA-treated animals revealed a significant days effect $\left(F_{(4,40)}=\right.$ $37.0 ; p<0.001)$, but neither a significant treatment effect $\left(F_{(1,10)}=2.6 ; p>0.1\right)$, nor a treatment $\times$ days interaction $\left(F_{(4,40)}=0.37 ; p>0.5\right)$. There was no significant difference in escape latencies on the first trial of day 1 . In contrast with the escape latencies, analysis of the swim distances (Fig. $4 F$ ) revealed a significant treatment effect $\left(F_{(1,10)}=5.90 ; p<0.05\right)$. Discrepancies between the escape latencies and swim distances could be attributed to differences in the swim speeds of the saline- and $\beta$-FNA-treated animals (Fig. $4 G)$, although this did not reach significance $\left(F_{(1,10)}=3.35 ; p=0.097\right)$.

The effect of $\beta$-FNA on spatial memory formation $11 \mathrm{~d}$ after injection, as measured by the percentage of time spent in the correct quadrant, is seen in Figure $4 H$. $\beta$-FNA remains effective $11 \mathrm{~d}$ after injection, causing a significant impairment in spatial memory formation on probe day 1 but not on probe days 3 and 5. Saline- and $\beta$-FNA-treated animals spent a similar amount of time in the correct quadrant on the first trial of day 1 . However, by the end of training on day 1 (probe day 1) there was a significant increase in the amount of time spent in the correct quadrant compared with trial 1 for the saline-treated animals ( $p=0.005$ ) but not for the $\beta$-FNA-treated animals $(p>0.1)$. A two-way repeated-measures ANOVA of the percentage of time spent in the correct quadrant between the saline- and the $\beta$-FNA-treated animals showed a significant treatment effect $\left(F_{(1,10)}=6.0 ; p<0.05\right)$ and a significant treatment $\times$ probe day interaction $\left(F_{(2,20)}=3.5 ; p=0.05\right)$. Subsequent comparisons using the Student-Newman-Keuls test showed that the $\beta$-FNA-treated animals spent significantly less time in the correct quadrant than saline controls on probe day 1 $(p=0.001)$ but not on days 3 or $5(p>0.5)$. These data are in agreement with the reversal learning data in experiment 1 (Fig. $4 D)$.

\section{Injections of $\beta$-FNA into the dorsal CA3 region impairs spatial memory retrieval}

The previous findings suggest that the memory retention deficit observed in the $\beta$-FNA-treated animals (Fig. 3) may be attributable to an impairment in memory retrieval mechanisms. To investigate this finding further, animals were pretrained in the water maze in the absence of drug, then were given $\beta$-FNA $2 \mathrm{~d}$ before the retention test (Fig. 5A). By the end of pretraining, both groups learned to locate the platform, reaching escape latencies $<13 \mathrm{sec}$ (Fig. 5C). No significant group differences were found in escape latencies, distance to platform, thigmotaxis, or swim speeds $\left(F_{(1,20)}<1\right.$ for each). Moreover, no significant differences were found in probe trial performance (Fig. 5D) (treatment effect, $\left.F_{(1,20)}=0.61 ; p>0.1\right)$.

Four days after the completion of pretraining (day 9), animals received a single bilateral injection of either $0.9 \%$ saline or $\beta$-FNA $(40 \mathrm{nmol})$ into the dorsal hippocampal CA3 region. Two days later (day 11), animals were given a spatial probe test to determine the effects of $\beta$-FNA on spatial memory retrieval. As seen in Figure $5 E, \beta$-FNA treatment caused a significant impairment in 

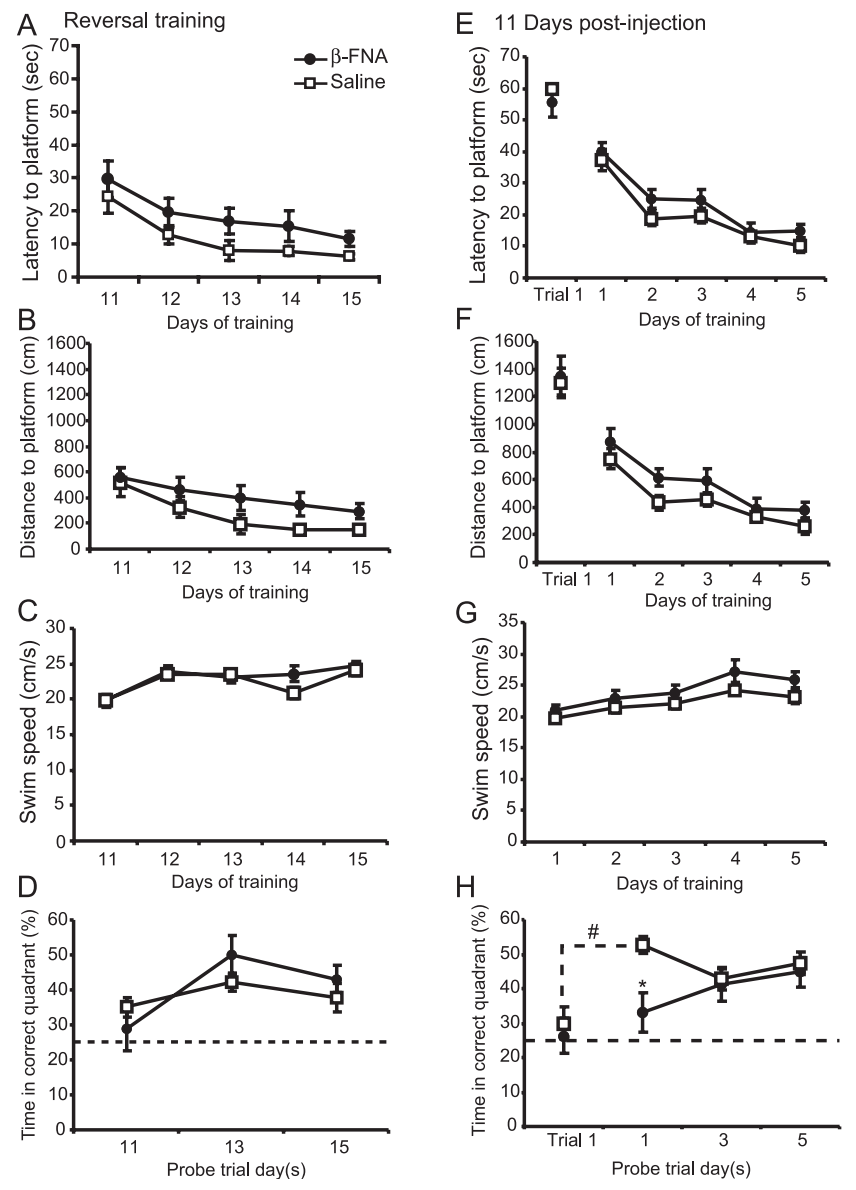

Figure 4. Effects of $\beta$-FNA on learning $11 \mathrm{~d}$ after injection. Escape latencies $(A)$, distance traveled $(B)$, and swim speeds ( $C$ during reversal training for the animals treated with $\beta$-FNA (solid circles) and saline (open squares). D, The percentage of time spent in the correct quadrant was determined (means \pm SEM) during reversal probe trials on days 11,13 , and 15 . Escape latency $(E)$, distance traveled $(F)$, and swim speed $(G)$ for a separate group of animals trained in the water maze for 5 consecutive days starting $11 \mathrm{~d}$ after injection. Spatial probe trials were given after the first, third, and fifth day of training. $H$, The percentage of time spent in the correct quadrant during the during the probe trials and on the first trial of day 1 . The dashed line represents chance performance levels (25\%). Significant differences were found. ${ }^{*} p=0.005$ versus trial $1 ;{ }^{*} p=0.001$ versus saline control.

spatial memory retrieval. Saline-treated pretrained animals focused their search predominantly in the correct quadrant, unlike the $\beta$-FNA-treated pretrained animals. A two-way repeatedmeasures ANOVA of the percentage of time spent in the four quadrants between the pretrained saline and $\beta$-FNA-treated animals found a significant treatment $\times$ quadrant interaction $\left(F_{(3,60)}=2.75 ; p=0.05\right)$. Analysis of the percentage of time spent searching within a $53 \mathrm{~cm}$ diameter zone around the platform location and corresponding zones (chance performance = $12.5 \%)$ also found a significant treatment $\times$ zone interaction $\left(F_{(3,60)}=6.60 ; p<0.001\right)$. Subsequent analysis using the Student-Newman-Keuls test showed that the $\beta$-FNA-treated pretrained animals spent significantly less time in the correct quadrant zone compared with the saline-treated animals $(p<0.001)$.

Pretraining did not prevent spatial learning impairments induced by $\beta$-FNA treatment (Fig. $6 A-D$ ). Saline-treated animals took less time to locate the platform and spent less time in the outer $20 \%$ of the pool (thigmotaxis) compared with pretrained $\beta$-FNA-treated animals. A two-way repeated-measures ANOVA of escape latencies (Fig. $6 A$ ) between the pretrained saline- and $\beta$-FNA-treated animals found a significant treatment effect (square root transformed, $F_{(1,20)}=4.55 ; p<0.05$; days effect, $\left.F_{(4,80)}=21.65 ; p<0.001\right)$, but no treatment $\times$ days interaction $\left(F_{(4,80)}=1.21 ; p>0.1\right)$. Similar results were found for swim distances (Fig. $6 B$ ) (treatment effect, $F_{(1,20)}=6.42 ; p<0.05$; days effect, $\left.F_{(4,80)}=24.1 ; p<0.001\right)$ and thigmotaxis (Fig. $6 C$ ) (treatment effect, $F_{(1,20)}=9.96 ; p=0.005$; days effect, $F_{(4,80)}=18.0$; $p<0.001)$. Importantly, no significant differences in swim speeds were found during the reversal training (Fig. 6D) (treatment effect, $\left.F_{(1,20)}=1.34 ; p>0.1\right)$.

Despite the impaired performance, the pretrained $\beta$-FNAtreated animals formed a spatial memory for the new platform position (Fig. 6E). A two-way repeated-measures ANOVA of the percentage of time spent in the correct quadrant over probe days 11,13 , and 15 revealed no significant treatment effect $\left(F_{(1,20)}=\right.$ $1.38 ; p>0.1)$. Although it seems that the pretrained $\beta$-FNAtreated animals spent less time in the correct quadrant than the pretrained saline-treated animals on probe day 11 (38.2 $\pm 2.7 \mathrm{vs}$ $44.1 \pm 4.5 \%$, respectively) and day 13 (41.6 \pm 2.3 vs $44.2 \pm 3.9 \%$, respectively), these differences were not significant $(p>0.05)$.

\section{Discussion}

The present study shows that $\mu$-opioid receptors in the dorsal CA3 region of the hippocampus play an important role in the acquisition and retrieval of spatial memory. Blocking $\mu$-opioid receptors with $\beta$-FNA ( $40 \mathrm{nmol}$ ) significantly impairs the acquisition of spatial learning in both naive and pretrained animals, as measured by escape latency, without causing sensorimotor deficits. $\beta$-FNA also significantly impairs the rate of spatial memory formation and causes memory retrieval deficits after a $6 \mathrm{~d}$ retention interval, as measured by probe trial performance. Animals are, however, able to learn a new task once receptor levels replenish. These data are in agreement with computational models of CA3 function (McNaughton and Morris, 1987; Hasselmo et al., 1995; Kesner et al., 2000) and supports the hypothesis that the mossy-fiber and perforant pathways to CA3 are important for spatial learning and memory retrieval (Treves and Rolls, 1994).

One of the advantages of using $\beta$-FNA in this study was that it produced a long-lasting antagonism of $\mu$-opioid receptors after a single injection. The results of the receptor binding studies show that a single application of $\beta$-FNA $(40 \mathrm{nmol})$ depleted $\mu$-opioid receptors in the CA3 region to $50.8 \%$ of control levels $24 \mathrm{hr}$ after injection. However, by $11 \mathrm{~d}$ after injection, $\mu$-opioid receptor levels returned to $86.9 \%$ of control levels. These results are consistent with studies by Martin et al. $(1995,1998)$, who showed that intracerebroventricular injections of $\beta$-FNA ( $40 \mathrm{nmol}$ ) effectively reduced $\left[{ }^{3} \mathrm{H}\right]\left[\mathrm{D}-\mathrm{Ala}^{2}-\mathrm{N}-\mathrm{Me}-\mathrm{Phe}^{4}\right.$-Gly-ol $\left.{ }^{5}\right]$-enkephalin binding to $\mu$-opioid receptors by $34-50 \%$ in the rat brain $24 \mathrm{hr}$ after injection, and estimated the half-life of recovery of $\mu$-opioid receptors to be $10.3 \pm 1.4$ (mean \pm SEM) d. The time course of the inhibitory effects of $\beta$-FNA on spatial learning observed here are consistent with antagonistic effects of $\beta$-FNA found in rats trained to self-administer heroin (Martin et al., 1995, 1998), suggesting that the behavioral responses (i.e., learning and self-administration) return at a rate that parallels the return of functional $\mu$-opioid-receptor binding sites. Given the location of the injections and spread of $\beta$-FNA (Fig. $1 B, C$ ) it is possible that in some animals $\beta$-FNA may have reached the molecular layer of the dentate gyrus; however, our judgment is that the observed learning deficits are most likely attributable to the blockade of CA $3 \mu$-opioid receptors. The role of $\mu$-opioid receptors in the dentate gyrus for spatial learning remains to be determined.

The results of this study are similar to those of Handelmann and Olton (1981) and others (Sutherland et al., 1983; StubleyWeatherly et al., 1996; Steffenach et al., 2002), who showed that 
A

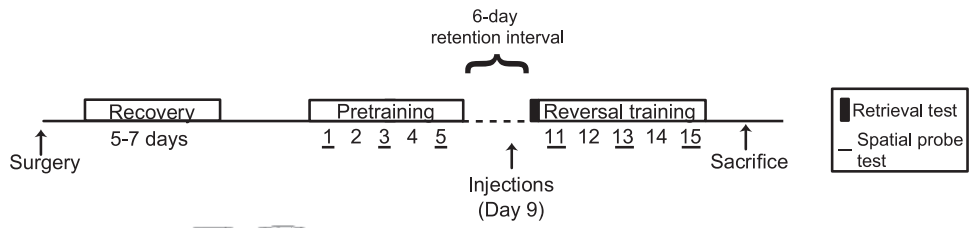

B
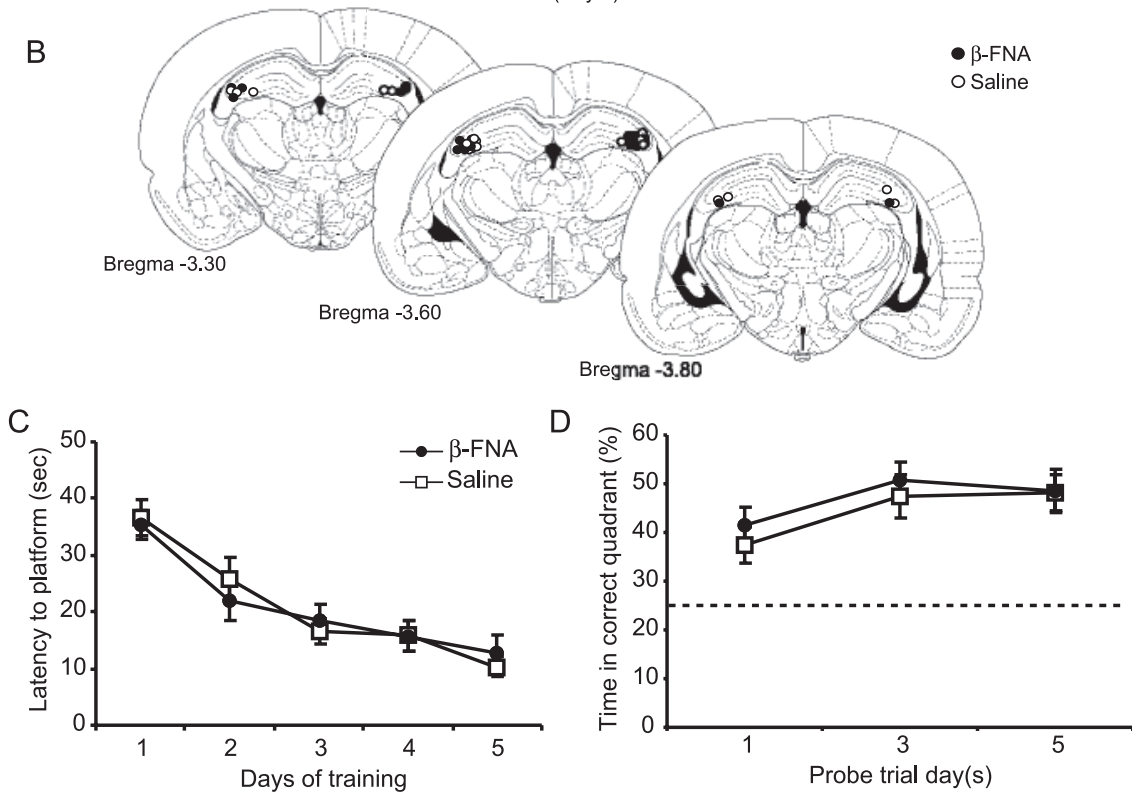

$E$

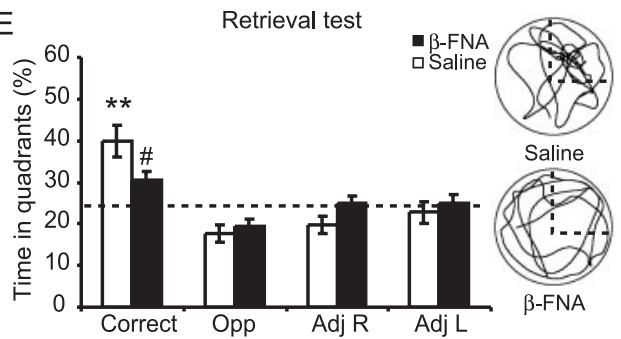

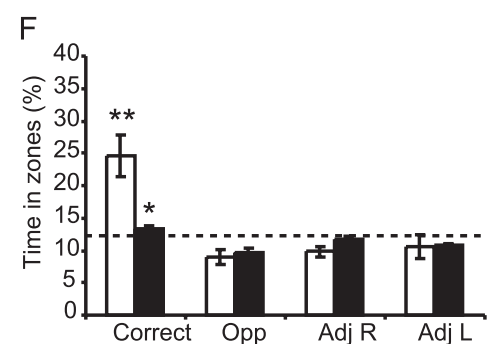

Figure 5. Effects of $\beta$-FNA on spatial memory retrieval in pretrained animals. $A$, A separate group of animals was first pretrained, then injected with $\beta$-FNA or saline $2 \mathrm{~d}$ before a retrieval test and reversal training. $B$, Location of cannula tips for the animals treated with $\beta$-FNA (filled circles) and saline (open circles). Plates were adapted from Paxinos and Watson (1998). C, Escape latency during spatial pretraining (in the absence of drug) between the animals to be treated with $\beta$-FNA (filled circles) or saline (open squares). D, The percentage of time spent in the correct quadrant during the pretraining probe trials (means $\pm S E M$ ). Effects of $\beta$-FNA on spatial memory retrieval for the previously learned platform position $(E, F)$. The percentage of time spent in the correct and the three other corresponding quadrants $(E)$, or within a $53 \mathrm{~cm}$ diameter zone around the platform $(F)$, was determined (means \pm SEM) for the animals treated with $\beta$-FNA (black columns) and saline (white columns). Note that the pretrained $\beta$-FNA-treated animals are spending close to chance levels in all quadrants (25\%) and zones (12.5\%). The right column in $E$ shows representative swim paths for animals treated with saline (top) and $\beta$-FNA (bottom). Significant differences were found. ${ }^{\#} p=0.05 ;{ }^{*} p<0.05$ versus saline control; ${ }^{* *} p<0.05$ versus all other quadrants or zones. The dashed line outlines correct quadrant.

the integrity of CA3 pyramidal cells or the synaptic connections within the CA3 region are important for spatial learning in both naive or pretrained animals. Using a within-animal design, we showed that $\beta$-FNA significantly impaired spatial learning while $\mu$-opioid receptors in the CA3 region were blocked and that animals could learn a new task once $\mu$-receptors levels replenished. The later results were confirmed with a second group of animals trained $11 \mathrm{~d}$ after injection (Fig. 4).

In both naive and pretrained animals, $\beta$-FNA caused a significant impairment in escape latencies and swim distances (Figs. 2, 6). The spatial learning impairments induced by $\beta$-FNA were specific for the CA3 region, because injections of $\beta$-FNA into the lateral ventricles did not impair spatial learning. This is consistent with findings by Martin et al. (1993), who showed that intracerebroventricular injections of $\beta$-FNA ( $40 \mathrm{nmol})$ did not significantly reduce $\mu$-opioid receptors in the hippocampus (fields CA1-CA3) or dentate gyrus. Moreover, the observed acquisition impairments were not caused by sensorimotor deficits commonly seen in the presence of NMDA-receptor antagonists (Morris, 1989; Saucier and Cain, 1995; Saucier et al., 1996), because there were no differences in the ability of the $\beta$-FNA-treated animals to climb onto the platform once found (experimenter's observation); there were no differences in swim speeds (Figs. $2 D, 6 D$ ) or visual platform learning (Fig. 2E).

$\beta$-FNA-treated animals did, however, take a more circuitous route to locate the platform, leading to an increased thigmotaxic behavior in both naive (Fig. 2C) and pretrained animals (Fig. $6 C$ ). This circuitous behavior does not imply that $\beta$-FNA causes sensorimotor deficits (Devan and White, 1999; Devan et al., 1999; Hoh et al., 1999), but instead may reflect a shift from using a spatial search strategy to locate the platform, to a more praxic or taxic strategy (O'Keefe and Nadel, 1978). Similar changes in search strategy (i.e., increased thigmotaxic behavior) are commonly seen in hippocampal lesioned naive and pretrained animals (Sutherland et al., 1983; DiMattia and Kesner, 1988). Together, these results suggest that regardless of previous experience, $\mu$-opioid receptors in the dorsal CA3 region play a significant role in the acquisition of spatial water maze learning; however, pretraining prevents the $\beta$-FNA-induced memory impairments as measured by probe trial performance.

Inactivation of $\mu$-opioid receptors with $\beta$-FNA significantly impaired the rate of spatial memory formation during the initial training (Fig. $2 F$ ). The inability of the $\beta$-FNA-treated animals to form a longlasting spatial memory at a rate comparable with saline-treated controls suggests that there is a deficit in opioid-receptordependent plasticity. $\mu$-Opioid receptor activation is critical for the induction of LTP in both the mossy-fiber and lateral perforant path synapses to CA3 (Derrick et al., 1992; Derrick and Martinez, 1994a; Williams and Johnston, 1996), whereas $\kappa$-opioid receptor activation blocks mossy-fiber LTP (Weisskopf et al., 1993; Simmons and Chavkin, 1996a). As stated previously, $\beta$-FNA has long-lasting $(>48 \mathrm{hr}) \mu$-opioid receptor antagonistic activities in addition to short-term $(<3-6 \mathrm{hr}) \kappa$-opioid receptor agonistic activities (Ward et al., 1982). One can argue that the observed effects of $\beta$-FNA in the present study are attributable to its possible agonistic action on $\kappa$-opioid receptors, because repeated intrahippocampal injections of the $\kappa$-agonist dynorphin impairs water maze learning in rats (McDaniel et al., 1990; 


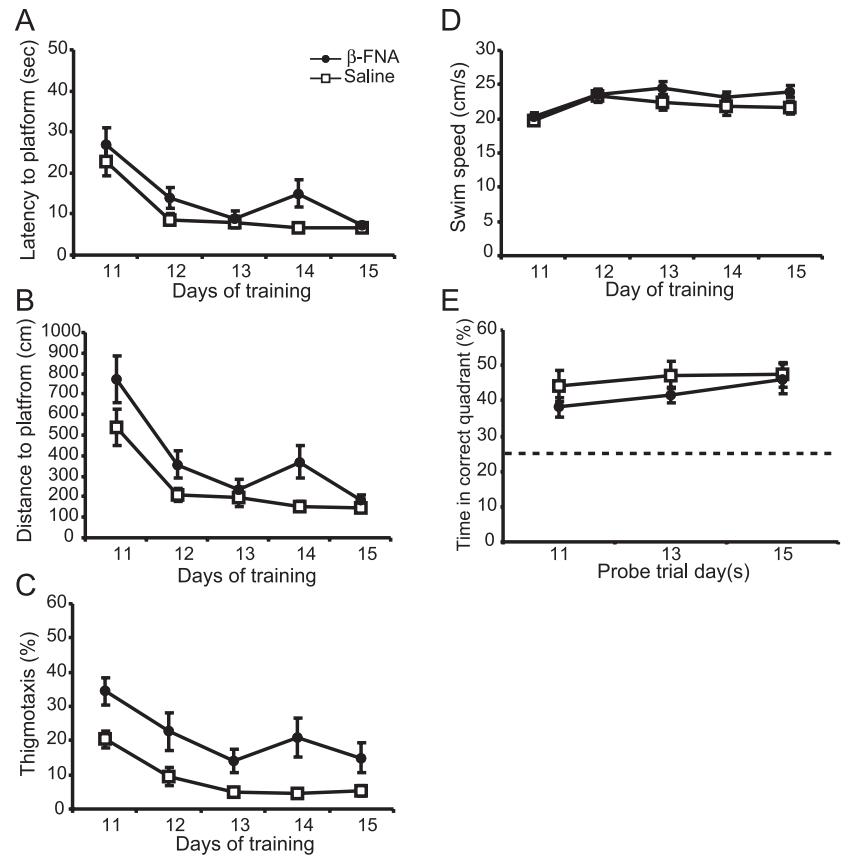

Figure 6. Effects of $\beta$-FNA on spatial reversal learning and memory in pretrained animals. Mean \pm SEM escape latencies $(A)$, swim distances $(B)$, amount of time spent swimming in the outer $20 \%$ of the pool (thigmotaxis) ( $C$, and swim speeds $(D)$ during the $5 \mathrm{~d}$ of reversal training between pretrained animals treated with $\beta$-FNA (solid circles) and saline (open squares). E, The percentage of time spent in the correct quadrant was determined (mean \pm SEM) during reversal probe trials on days 11,13 , and 15 . The dashed line represents chance performance levels (25\%).

Sandin et al., 1998). Although possible, this seems unlikely, because the short-term $\kappa$-agonistic activity of $\beta$-FNA $(<3-6 \mathrm{hr})$ would not account for the impaired probe trial performance seen up to $11 \mathrm{~d}$ after injection. Therefore, spatial memory impairments caused by $\beta$-FNA are likely caused by the long-lasting inactivation of $\mu$-opioid receptors and subsequent blockade of $\mu$-opioid-receptor-dependent plasticity. This conclusion is further supported by the recent findings showing impairments in the induction of both mossy-fiber LTP to CA3, lateral perforant path LTP to CA3 and dentate, and impairments in spatial water maze learning in certain strains of $\mu$-opioid-receptor-deficient mice (Matthies et al., 2000; Jamot et al., 2003; Jang et al., 2003).

Although the $\beta$-FNA-treated animals formed a spatial memory for the platform location by probe day 5 (Fig. $2 \mathrm{~F}$ ), this memory was not stable, and a significant amount of forgetting occurred over a $6 \mathrm{~d}$ retention period compared with saline-treated controls (Fig. 3A). Because the effects of $\beta$-FNA could still be seen $11 \mathrm{~d}$ after injection (Fig. $4 H$ ), an alternative explanation for the poor retention test performance by the $\beta$-FNA-treated animals was that there was a memory retrieval deficit. We confirmed this finding by first pretraining animals, then giving $\beta$-FNA or saline $2 \mathrm{~d}$ before the retention test (Fig. 5), and indeed found a retrieval deficit in the $\beta$-FNA-treated animals. Together, these data are consistent with previous lesion studies demonstrating that the integrity of the CA3 region is necessary for the retrieval of spatial memory (Handelmann and Olton, 1981; Stubley-Weatherly et al., 1996; Steffenach et al., 2002), and suggests that CA3 $\mu$-opioid receptors play an important role in spatial memory retrieval.

Our behavioral findings are in agreement with several computational models predicting the function of the CA3 region in memory encoding and retrieval (Marr, 1971; McNaughton and Morris, 1987; Treves and Rolls, 1994; Hasselmo et al., 1995). For instance, studies by Treves and Rolls $(1992,1994)$ predict that temporary inactivation of the mossy-fiber and perforant pathways to CA3 would impair new learning by preventing the activation of CA3 pyramidal cells and altering the subsequent synaptic modifications occurring at the CA3 recurrent and perforant path synapses. The mossy-fiber synapses are thought to be particularly important during learning, because of their large size and potential to initiate CA3 firing, which drives or forces network output. Interestingly, Henze et al. (2002) recently found that a single dentate granule cell is capable of inducing firing in CA3 pyramidal cells, in vivo, after high-frequency stimulation $(100 \mathrm{~Hz})$ or behaviorally relevant stimulation containing highfrequency episodes. This is intriguing, because high-frequency stimulation is necessary for the release of opioid peptides (Wagner et al., 1990) and for the induction of mossy-fiber and lateralperforant-path LTP (Derrick and Martinez, 1994b; Williams and Johnston, 1996; Do et al., 2002). Indeed, we found that blocking $\mu$-opioid receptors in the dorsal hippocampal CA3 region significantly impaired the acquisition of a spatial water maze task and impaired performance on spatial probe trials.

One of the proposed computational functions of the CA3 region is pattern completion (Marr, 1971; McNaughton and Morris, 1987); that is, when the CA3 is presented with a partial sequence of events (or spatial cues), the CA3 is able to recreate the complete pattern of events by activating the recurrent collaterals. The model proposed by Treves and Rolls (Treves and Rolls, 1992, 1994; Rolls, 1996) suggests that the perforant path, but not the mossy-fiber pathway to CA3, is necessary for the retrieval of episodic memory. Although our data do not allow us to distinguish between the pathways, $\beta$-FNA treatment may have prevented the synaptic modifications occurring at the mossy-fiber and lateral perforant path to CA3 synapses during learning, in addition to preventing the activation of synapses necessary for the retrieval of memory. Possible mechanisms include disrupting synaptic transmission or plasticity in these pathways (Przewlocki et al., 1999; Kearns et al., 2001) or altering the excitability of CA3 pyramidal cells by modulating GABAergic inhibition (Martinez et al., 1979; Zieglgansberger et al., 1979; Jin and Chavkin, 1999). Unlike $\mu$-opioid receptors, genetic (Nakazawa et al., 2002) or pharmacological blockage (Lee and Kesner, 2002) of CA3 NMDA receptors do not impair spatial water maze learning or memory retrieval when tested in the same environment used for training, suggesting a differential role for CA3 $\mu$-opioid and NMDA receptors.

\section{References}

Bliss TV, Collingridge GL (1993) A synaptic model of memory: long-term potentiation in the hippocampus. Nature 361:31-39.

Bramham CR, Sarvey JM (1996) Endogenous activation of $\mu$ and $\delta_{1}$ opioid receptors is required for long-term potentiation induction in the lateral perforant path: dependence on GABAergic inhibition. J Neurosci 16:8123-8131.

Bramham CR, Errington ML, Bliss TV (1988) Naloxone blocks the induction of long-term potentiation in the lateral but not in the medial perforant pathway in the anesthetized rat. Brain Res 449:352-356.

Breindl A, Derrick BE, Rodriguez SB, Martinez Jr JL (1994) Opioid receptor-dependent long-term potentiation at the lateral perforant pathCA3 synapse in rat hippocampus. Brain Res Bull 33:17-24.

Chen C, Yin J, Riel JK, DesJarlais RL, Raveglia LF, Zhu J, Liu-Chen LY (1996) Determination of the amino acid residue involved in $\left[{ }^{3} \mathrm{H}\right]$ betafunaltrexamine covalent binding in the cloned rat mu-opioid receptor. J Biol Chem 271:21422-21429.

Conner-Kerr TA, Simmons DR, Peterson GM, Terrian DM (1993) Evidence for the corelease of dynorphin and glutamate from rat hippocampal mossy fiber terminals. J Neurochem 61:627-636.

Derrick BE, Martinez Jr JL (1994a) Opioid receptor activation is one factor 
underlying the frequency dependence of mossy fiber LTP induction. J Neurosci 14:4359-4367.

Derrick BE, Martinez Jr JL (1994b) Frequency-dependent associative longterm potentiation at the hippocampal mossy fiber-CA3 synapse. Proc Natl Acad Sci USA 91:10290-10294.

Derrick BE, Rodriguez SB, Lieberman DN, Martinez Jr JL (1992) Mu opioid receptors are associated with the induction of hippocampal mossy fiber long-term potentiation. J Pharmacol Exp Ther 263:725-733.

Devan BD, White NM (1999) Parallel information processing in the dorsal striatum: relation to hippocampal function. J Neurosci 19:2789-2798.

Devan BD, McDonald RJ, White NM (1999) Effects of medial and lateral caudate-putamen lesions on place- and cue-guided behaviors in the water maze: relation to thigmotaxis. Behav Brain Res 100:5-14.

DiMattia BD, Kesner RP (1988) Spatial cognitive maps: differential role of parietal cortex and hippocampal formation. Behav Neurosci 102:471-480.

Do VH, Martinez CO, Martinez Jr JL, Derrick BE (2002) Long-term potentiation in direct perforant path projections to the hippocampal CA3 region in vivo. J Neurophysiol 87:669-678.

Handelmann GE, Olton DS (1981) Spatial memory following damage to hippocampal CA3 pyramidal cells with kainic acid: impairment and recovery with preoperative training. Brain Res 217:41-58.

Harris EW, Cotman CW (1986) Long-term potentiation of guinea pig mossy fiber responses is not blocked by $\mathrm{N}$-methyl-D-aspartate antagonists. Neurosci Lett 70:132-137.

Hasselmo ME, Schnell E, Barkai E (1995) Dynamics of learning and recall at excitatory recurrent synapses and cholinergic modulation in rat hippocampal region CA3. J Neurosci 15:5249-5262.

Henze DA, Wittner L, Buzsaki G (2002) Single granule cells reliably discharge targets in the hippocampal CA3 network in vivo. Nat Neurosci 5:790-795.

Hoh T, Beiko J, Boon F, Weiss S, Cain DP (1999) Complex behavioral strategy and reversal learning in the water maze without NMDA receptordependent long-term potentiation. J Neurosci 19:RC2(1-5).

Holscher C (1999) Stress impairs performance in spatial water maze learning tasks. Behav Brain Res 100:225-235.

Ishizuka N, Weber J, Amaral DG (1990) Organization of intrahippocampal projections originating from CA3 pyramidal cells in the rat. J Comp Neurol 295:580-623.

Jamot L, Matthes HW, Simonin F, Kieffer BL, Roder JC (2003) Differential involvement of the mu and kappa opioid receptors in spatial learning. Genes Brain Behav 2:80-92.

Jang CG, Lee SY, Yoo JH, Yan JJ, Song DK, Loh HH, Ho IK (2003) Impaired water maze learning performance in mu-opioid receptor knockout mice. Brain Res Mol Brain Res 117:68-72.

Jin W, Chavkin C (1999) Mu opioids enhance mossy fiber synaptic transmission indirectly by reducing GABAB receptor activation. Brain Res 821:286-293.

Kearns IR, Morton RA, Bulters DO, Davies CH (2001) Opioid receptor regulation of muscarinic acetylcholine receptor-mediated synaptic responses in the hippocampus. Neuropharmacology 41:565-573.

Kesner RP, Gilbert PE, Wallenstein GV (2000) Testing neural network models of memory with behavioral experiments. Curr Opin Neurobiol 10:260-265.

Lauri SE, Bortolotto ZA, Bleakman D, Ornstein PL, Lodge D, Isaac JT, Collingridge GL (2001) A critical role of a facilitatory presynaptic kainate receptor in mossy fiber LTP. Neuron 32:697-709.

Lee I, Kesner RP (2002) Differential contribution of NMDA receptors in hippocampal subregions to spatial working memory. Nat Neurosci 5:162-168.

Liu-Chen LY, Li SX, Lewis ME (1991) Autoradiographic study of irreversible binding of $\left[{ }^{3} \mathrm{H}\right]$ beta-funaltrexamine to opioid receptors in the rat forebrain: comparison with mu and delta receptor distribution. Brain Res 544:235-242.

Mansour A, Khachaturian H, Lewis ME, Akil H, Watson SJ (1987) Autoradiographic differentiation of $\mu, \delta$, and $\kappa$ opioid receptors in the rat forebrain and midbrain. J Neurosci 7:2445-2464.

Marr D (1971) Simple memory: a theory for archicortex. Philos Trans R Soc Lond B Biol Sci 262:23-81.

Martin TJ, Dworkin SI, Smith JE (1993) Effects of intracerebroventricular administration of beta-funaltrexamine on $\left[{ }^{3} \mathrm{H}\right]$ DAMGO binding to rat brain sections. J Pharmacol Exp Ther 267:506-514.
Martin TJ, Dworkin SI, Smith JE (1995) Alkylation of mu opioid receptors by beta-funaltrexamine in vivo: comparison of the effects on in situ binding and heroin self-administration in rats. J Pharmacol Exp Ther 272:1135-1140.

Martin TJ, DeMontis MG, Kim SA, Sizemore GM, Dworkin SI, Smith JE (1998) Effects of beta-funaltrexamine on dose-effect curves for heroin self-administration in rats: comparison with alteration of $\left[{ }^{3} \mathrm{H}\right] \mathrm{DAMGO}$ binding to rat brain sections. Drug Alcohol Depend 52:135-147.

Martinez Jr JL, Jensen RA, Creager R, Veliquette J, Messing RB, McGaugh JL, Lynch G (1979) Selective effects of enkephalin on electrical activity of the in vitro hippocampal slice. Behav Neural Biol 26:128-131.

Matthies H, Schroeder H, Becker A, Loh H, Hollt V, Krug M (2000) Lack of expression of long-term potentiation in the dentate gyrus but not in the CA1 region of the hippocampus of mu-opioid receptor-deficient mice. Neuropharmacology 39:952-960.

McDaniel KL, Mundy WR, Tilson HA (1990) Microinjection of dynorphin into the hippocampus impairs spatial learning in rats. Pharmacol Biochem Behav 35:429-435.

McNaughton BL, Morris RGM (1987) Hippocampal synaptic enhancement and information storage within a distributed memory system. Trends Neurosci 10:408-415.

Meilandt WJ, Grisby JM, Keel JM, Barea-Rodriguez EJ, Martinez Jr JL (1999) Intrahippocampal administration of the $\mu$-opioid receptor antagonist $\beta$-funaltrexamine into area CA3 impairs spatial learning in rats. Soc Neurosci Abstr 25:2159.

Morris RG (1989) Synaptic plasticity and learning: selective impairment of learning rats and blockade of long-term potentiation in vivo by the NMDA receptor antagonist AP-5. J Neurosci 9:3040-3057.

Morris RG, Garrud P, Rawlins JN, O'Keefe J (1982) Place navigation impaired in rats with hippocampal lesions. Nature 297:681-683.

Moser E, Moser MB, Andersen P (1993) Spatial learning impairment parallels the magnitude of dorsal hippocampal lesions, but is hardly present following ventral lesions. J Neurosci 13:3916-3925.

Moser MB, Moser EI (1998) Distributed encoding and retrieval of spatial memory in the hippocampus. J Neurosci 18:7535-7542.

Nakazawa K, Quirk MC, Chitwood RA, Watanabe M, Yeckel MF, Sun LD, Kato A, Carr CA, Johnston D, Wilson MA, Tonegawa S (2002) Requirement for hippocampal CA3 NMDA receptors in associative memory recall. Science 30:30.

O'Keefe J, Nadel L (1978) The hippocampus as a cognitive map. London: Oxford UP.

Olton DS, Walker JA, Gage FH (1978) Hippocampal connections and spatial discrimination. Brain Res 139:295-308.

Paxinos G, Watson C (1998) The rat brain in stereotaxic coordinates, Ed 4. San Diego: Academic.

Portoghese PS, Larson DL, Sayre LM, Fries DS, Takemori AE (1980) A novel opioid receptor site directed alkylating agent with irreversible narcotic antagonistic and reversible agonistic activities. J Med Chem 23:233-234.

Przewlocki R, Parsons KL, Sweeney DD, Trotter C, Netzeband JG, Siggins GR, Gruol DL (1999) Opioid enhancement of calcium oscillations and burst events involving NMDA receptors and L-type calcium channels in cultured hippocampal neurons. J Neurosci 19:9705-9715.

Riedel G, Micheau J, Lam AG, Roloff E, Martin SJ, Bridge H, Hoz L, Poeschel B, McCulloch J, Morris RG (1999) Reversible neural inactivation reveals hippocampal participation in several memory processes. Nat Neurosci 2:898-905.

Rolls ET (1996) A theory of hippocampal function in memory. Hippocampus 6:601-620.

Rothman RB, Long JB, Bykov V, Jacobson AE, Rice KC, Holaday JW (1988) $\beta$-FNA binds irreversibly to the opiate receptor complex: in vivo and in vitro evidence. J Pharmacol Exp Ther 247:405-416.

Sandin J, Nylander I, Georgieva J, Schott PA, Ogren SO, Terenius L (1998) Hippocampal dynorphin B injections impair spatial learning in rats: a kappa-opioid receptor-mediated effect. Neuroscience 85:375-382.

Saucier D, Cain DP (1995) Spatial learning without NMDA receptordependent long-term potentiation. Nature 378:186-189.

Saucier D, Hargreaves EL, Boon F, Vanderwolf CH, Cain DP (1996) Detailed behavioral analysis of water maze acquisition under systemic NMDA or muscarinic antagonism: nonspatial pretraining eliminates spatial learning deficits. Behav Neurosci 110:103-116.

Simmons ML, Chavkin C (1996a) $\kappa$-Opioid receptor activation of a 
dendrotoxin-sensitive potassium channel mediates presynaptic inhibition of mossy fiber neurotransmitter release. Mol Pharmacol 50:80-85.

Simmons ML, Chavkin C (1996b) Endogenous opioid regulation of hippocampal function. Int Rev Neurobiol 39:145-196.

Steffenach HA, Sloviter RS, Moser EI, Moser MB (2002) Impaired retention of spatial memory after transection of longitudinally oriented axons of hippocampal CA3 pyramidal cells. Proc Natl Acad Sci USA 99:3194-3198.

Stengaard-Pedersen K (1983) Comparative mapping of opioid receptors and enkephalin immunoreactive nerve terminals in the rat hippocampus: a radiohistochemical and immunocytochemical study. Histochemistry 79:311-333.

Stubley-Weatherly L, Harding JW, Wright JW (1996) Effects of discrete kainic acid-induced hippocampal lesions on spatial and contextual learning and memory in rats. Brain Res 716:29-38.

Sutherland RJ, Whishaw IQ, Kolb B (1983) A behavioural analysis of spatial localization following electrolytic, kainate- or colchicine-induced damage to the hippocampal formation in the rat. Behav Brain Res 7:133-153.

Takemori AE, Larson DL, Portoghese PS (1981) The irreversible narcotic antagonistic and reversible agonistic properties of the fumaramate methyl ester derivative of naltrexone. Eur J Pharmacol 70:445-451.

Treves A, Rolls ET (1992) Computational constraints suggest the need for two distinct input systems to the hippocampal CA3 network. Hippocampus 2:189-199.
Treves A, Rolls ET (1994) Computational analysis of the role of the hippocampus in memory. Hippocampus 4:374-391.

Wagner JJ, Caudle RM, Neumaier JF, Chavkin C (1990) Stimulation of endogenous opioid release displaces mu receptor binding in rat hippocampus. Neuroscience 37:45-53.

Ward SJ, Portoghese PS, Takemori AE (1982) Pharmacological characterization in vivo of the novel opiate, beta-funaltrexamine. J Pharmacol Exp Ther 220:494-498.

Weisskopf MG, Zalutsky RA, Nicoll RA (1993) The opioid peptide dynorphin mediates heterosynaptic depression of hippocampal mossy fibre synapses and modulates long-term potentiation. Nature 362:423-427.

Williams SH, Johnston D (1996) Actions of endogenous opioids on NMDA receptor-independent long-term potentiation in area CA3 of the hippocampus. J Neurosci 16:3652-3660.

Yeckel MF, Kapur A, Johnston D (1999) Multiple forms of LTP in hippocampal CA3 neurons use a common postsynaptic mechanism. Nature Neurosci 2:625-633.

Zieglgansberger W, French ED, Siggins GR, Bloom FE (1979) Opioid peptides may excite hippocampal pyramidal neurons by inhibiting adjacent inhibitory interneurons. Science 205:415-417.

Zola-Morgan S, Squire LR, Amaral DG (1986) Human amnesia and the medial temporal region: enduring memory impairment following a bilateral lesion limited to field CA1 of the hippocampus. J Neurosci 6:29502967. 